\title{
Social and solidarity economy and access to food: Insights from Cameroon
}

\section{Economía social y solidaria y acceso a los alimentos: perspectivas de Camerún}

CIRIEC-UNED 202 1-103-94

DOI: $10.22458 /$ rna.v $12 \mathrm{i} 2.3768$

Nathanael Ojong, Ph.D.

York University, Deputy Director, Harriet Tubman Institute for

Research on Africa \& its Diasporas, Toronto, Canada,

nojong@yorku.ca, https://orcid.org/oooo-0001-6333-6335

\begin{abstract}
:
The social and solidarity economy has an increasingly important role in the issue of access to food. This article examines food solidarity in various low-income communities in Cameroon. In the foreground is a nuanced perspective on food distribution practices in the country; such practices allow the low-income population to have access to food. The methodology is qualitative; Interviews were conducted with the participants in English, French, and Pidgin. To facilitate the disclosure of information, it was clarified that the data provided will be anonymous (pseudonyms are used). In addition, for confidentiality reasons, no information that could reveal the identity of the participants is disclosed.
\end{abstract}

\section{RESUMEN:}

La economía social y solidaria tiene un papel cada vez más importante en el tema del acceso a la alimentación. Este artículo examina la solidaridad alimentaria en varias comunidades de bajos ingresos en Camerún. En primer plano se encuentra una perspectiva matizada sobre las prácticas de distribución de alimentos en el país; tales prácticas permiten que la población de bajos ingresos tenga acceso a los alimentos. La metodología es cualitativa; Las entrevistas se llevaron a cabo con los participantes en inglés, francés y pidgin. Para facilitar la divulgación de información, se aclaró que los datos proporcionados serán anónimos (se utilizan seudónimos). Además, por razones de confidencialidad, no se divulga información que pueda revelar la identidad de los participantes.

\section{RÉSUMÉ}

L'économie social et solidaire joue un rôle de plus en plus important dans le domaine de l'accès à l'alimentation. Cet article examine la solidarité alimentaire dans plusieurs communautés à faible revenu au Cameroun. Au premier plan se trouve une perspective nuancée sur les pratiques de distribution alimentaire dans le pays ; de telles pratiques permettent aux populations à faible revenu d'avoir accès à la nourriture. La méthodologie est qualitative ; les entretiens ont eu lieu avec les participants en anglais, français et Pidgin. Pour faciliter la divulgation d'informations, il a été précisé que les données fournies seront anonymes (pseudonymes utilisés). En outre, pour des raisons de confidentialité, aucune information susceptible de révéler l'identité des participants n’est divulguée.

\section{RESUMO:}

A economia social e solidária desempenha um papel cada vez mais importante na questão do acesso à alimentação. Este artigo examina a solidariedade alimentar em várias comunidades de baixa renda em Camarões. Em primeiro plano encontra -se uma perspectiva matizada sobre as práticas de distribuição de alimentos no país; tais práticas permitem que a população de baixa renda tenha acesso aos alimentos. A metodologia é qualitativa; As entrevistas foram realizadas com os participantes em inglês, francês e pidgin. Para facilitar a divulgação das informações, foi esclarecido que os dados fornecidos serão anônimos (são utilizados pseudônimos). Além disso, por motivos de sigilo, não são divulgadas informações que possam revelar a identidade dos participantes.

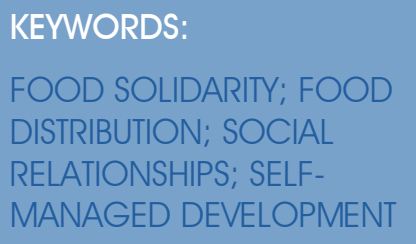

PALABRAS CLAVES:

SOLIDARIDAD

ALIMENTARIA;

DISTRIBUCION DE

COMIDA; RELACIONES

SOCIALES; DESARROLLO

AUTOGESTIÓN.
MOTS-CLÉS:

SOLIDARITÉ ALIMENTAIRE,

DISTRIBUTION DE

NOURRITURE,

RELATIONS SOCIALES,

DÉVELOPPPEMENT

AUTOGESTION.
PALAVRAS-CHAVE:

SOLIDARIEDADE

ALIMENTAR;

DISTRIBUIÇÃO

DE ALIMENTOS;

RELAÇÕES SOCIAIS;

DESENVOLVIMENTO DE

AUTO-GESTÃO. 


\section{INTRODUCTION}

The social and solidarity economy (SSE) has become a viable alternative to the neoliberal economic model, as it balances economic, social, and environmental objectives. The SSE recognises humankind not just as producers of economic wealth but also as co-owners of material wealth and co-users of natural resources, and as being co-responsible for the conservation of nature (Nembhard, 2020; Nembhard, 2014). Hence, people should strive to produce and share material wealth among all in order to generate sustainable conditions for the self-managed development of each and every member of society and the planet (Defourny et al., 2009; McMurtry, 2009; Mendell \& Neamtan, 2010; Utting, 2015; Veltmeyer, 2018).

The social and solidarity economy is increasingly playing an important role with respect to access to food, and here lies the focus of this paper. More precisely, this paper examines food solidarity in various low-income communities in Cameroon. I bring to the fore a nuanced perspective on food-sharing practices in the country, and argue that these practices thereby enable the low-income population there to have access to food.

The remainder of this paper is organised as follows. Section 2 sheds light on the conceptual framework, with Section 3 providing a contextual background to the study. Section 4 describes the method used in the paper, Section 5 presents and discusses the findings, and concluding remarks are provided in Section 6.

\section{Conceptualising the Social and Solidarity Economy}

The social and solidarity economy comprises a set of theories and practices that advocate for a more democratic, fair, and sustainable society (Loh \& Shear, 2015). It aspires to be "a socio-economic order and new way of life that deliberately chooses serving the needs of people and ecological sustainability as the goal of economic activity rather than maximization of profits under the unfettered rule of the market” (Quiñones, 2008, p. 13). The SSE frames its economic vision by taking into consideration the diverse ways that people meet their everyday material needs and care for one another (Gibson-Graham, 2006; McLaren \& Agyeman, 2015). Hence, the economy is intimately connected to social relations (Loh and Agyeman, 2019).

The work of Karl Polanyi is critical to the conceptualisation of the SSE. In The Great Transformation, Polanyi (2001) made the compelling point that earlier economies were embedded in the social sphere, and thus that social relations and structures were pivotal to their functioning. The 'social' principle espoused by Polanyi is fundamental to understanding the SSE, and he argued that other systems — reciprocity (involving symmetrical movements beyond a dual relationship), redistribution (involving movements from a central position), and householding (involving 'production for one's one use') - functioned before the dominance of the current market system (Polanyi, 2001, p. 55). Furthermore, Servet (2007) took the position that reciprocity goes beyond mere transaction in that it also entails complementary relationships premised on voluntary interdependence.

Arguably, the concept of the SSE is strongly associated with this conception of reciprocity, as actors in an SSE depend on one another to meet diverse needs, and their relationships are voluntary. Moreover, the concept of reciprocity carries a positive connotation of co-operation (Servet, 2007; Hillenkamp, 2013), which is evident in SSEs, since actors work co-operatively for both communal and societal benefit. In other words, emphasis is not placed on achieving material gain, and the various systems interact with one another in order to meet a variety of needs. For instance, some fair trade enterprises function based on the principle of reciprocity, but they can also make use of 'redistribution' in the form of support from the state (Sahakian \& Dunand, 2015). In a nutshell, Polanyi (2001) highlighted the plurality of economic principles, and these principles are manifested in SSEs.

Attempts have also been made to define the 'solidarity economy', but like the term 'social economy', there is no universally accepted definition. Laville (1992) defined the solidarity economy (économie solidaire in French) as a new generation of social economy with a plurality of forms of economic activities. A widely-used definition is that provided by Alliance 21 (2001), the group which convened the Working Group on the Solidarity Economy, which reads:

Solidarity economy designates all production, distribution and consumption activities that contribute to the democratization of the economy based on citizen commitments both at a local and global level $[\ldots]$ It covers different forms of organization that the population uses to create its own means of work or to have access to qualitative goods and services, in a dynamic of reciprocity and solidarity which links individual interests to the collective interest. (p. 11) 
This definition highlights the argument that the solidarity economy is not confined to a particular sector of the economy, as it cuts across different sectors. Emphasis is placed on certain values and priorities such as co-operation, equality, sustainability, democracy, diversity, justice, and local control (Allard \& Matthaei, 2008). Through this prism, it seems obvious that the 'social economy' and 'solidarity economy' have a lot in common. It is, therefore, unsurprising that increasingly, scholars and practitioners are using the term 'social and solidarity economy', which denotes the blending of elements from 'social economy' and 'solidarity economy'. According to Bateman (2015), the SSE might be viewed as 'an economic model that is stable, equitable, dignified, environmentally-sustainable and democratic or participative' (p. 150).

Clearly, SSE organisations and initiatives are diverse, yet in spite of this, they all focus on social welfare, co-operation, solidarity, ethics, and democratic self-management (Utting et al., 2014). Operating methods based on the solidarity principle aim to include rather than exclude, and goals are not limited to accumulating capital or generating profits but also to using resources to achieve objectives that will benefit the initiators as well as the workers and beneficiaries (Fonteneau et al., 2011). Achieving objectives also includes meeting the legitimate needs of all and shunning forms of consumerism that destroy nature and objectify social relationships (North \& Cato, 2017).

An SSE includes co-operatives, community-development trusts, mutual-benefit societies, worker-managed enterprises, and various forms of solidarity finance such as complementary currencies, rotating savings and credit associations, accumulative saving and credit associations, as well as social enterprises, fair trade networks, sharing schemes and associations, and community-based organisations. SSEs also incorporate practices such as the self-management of urban services by residents, networks of knowledge exchange, self-production, sustainable agriculture, organic produce channels, development of new activities by unemployed people, women's inter-cultural restaurants, collective kitchens, and other forms of collective enterprise (Eme \& Laville, 2006). Diversity and plurality are highlighted in all these organisations and initiatives (Gismondi et al., 2016; Laville, 2015; Lewis \& Conaty, 2012; Ojong, 2015).

The social and solidarity economy has been particularly vital in food movements. Food justice and sovereignty movements have been leading the challenge to the dominant food economy, which is based on corporate control of global industrialised production and informed by "free market principles" (McClintock, 2014; Holt, 2011 ; Agyeman \& McEntee, 2014; Holt \& Shattuck, 2011). In fact, these movements have championed solidarity approaches with respect to repossessing land, promoting fair trade networks, and creating cooperative organisations (Loh \& Agyeman, 2019).

\section{Contextual background}

Cameroon, with its history of colonial control by Germany, Britain, and France, and with English and French as its two official languages, has a population of about 25 million. According to the country's National Institute of Statistics (NIS) (2015), about $37.5 \%$ of the population lives below the national poverty line of 931 FCFA (US $\$$ 1.5) per day. The World Bank (2021) notes that the number of poor people in Cameroon actually increased by 12 $\%$ between 2007 and 2014, to about 8 million. Unemployment among those aged between 15 and 35 is about 13 $\%$, but crucially, underemployment is $71.9 \%$ at the national level, and $54.4 \%$ and $79.2 \%$ in urban and rural zones respectively (AfDB, 2012). Informal employment stands at $88.6 \%$ (NIS, 2015b).

A significant proportion of the population has experienced a long period of economic hardship, and for this segment of the population, the food question is a top priority. In January 2008, prices of basic commodities in the country were on average $40 \%$ higher than in the previous four months (Amin, 2012), leading to violent riots in major cities, with 24-100 people reportedly killed (Berazneva \& Lee, 2013). According to the United Nations, there was significant increase in food insecurity between 2013 and 2016, with 2.6 million people in the country being foodinsecure in 2017, increasing to 3.9 million in 2018 (WFP, 2018). Food insecurity in Cameroon is common among smallholder farmers and most rain-fed dependent communities (Mbuli et al., 2021). 


\section{METHODOLOGY}

The nature of the research required a qualitative approach, and for that reason I conducted interviews. The research participants were proficient in either English, French, and/or Pidgin. A translator was not needed due to my knowledge of these languages. To facilitate disclosure of information, it was made clear that any information provided would not be passed on to any third party and would be anonymised. Hence, pseudonyms are used in this paper. Also, for confidentiality purposes, I do not disclose any information which might reveal the identity of the participants.

The study was conducted in four administrative regions (formerly provinces) in the country - the Northwest, Southwest, Littoral, and Central. More precisely, the research sites in the Northwest Region were Bamenda, Bafut, Belo, Fundong, Fungom, and Wum, while Buea was the research zone in the Southwest Region. Finally, Douala and Yaoundé were the research sites in the Littoral and Central regions, respectively. Some of these research sites are classified as urban areas, while others are rural communities.

Interviews were recorded using a digital voice recorder, and I took notes by hand. The audio-recordings were transcribed, and interviews conducted in French and Pidgin were translated into English and coded using NVIVO.

Participants were engaged in agriculture (the cultivation of yams, maize, vegetables, beans, plantains, coffee, ginger, plantains, groundnuts); beekeeping; fishkeeping; goat, pig, and poultry farming; petty trading (e.g., the sale of roasted fish and plantains, cigarettes, sugar, biscuits, firewood, gasoline, fresh fish, corn beer, etc.); mobile street food vending; operating motorbike taxis and mobile phone booths; selling crushed stones; tailoring; and the sale of and second-hand clothes, footwear, body lotion, kitchen utensils, bedsheets and covers, etc.

\section{THE DYNAMICS OF FOOD SOLIDARITY IN CAMEROON}

In several communities in Cameroon, food-sharing symbolises conviviality and harmonious co-existence. In other words, it conjures up positive images of community. In rural communities in particular, sharing food or inviting friends and neighbours to share a meal is a normal everyday practice. As explained by Akenji:

I don't enjoy having a meal alone; I like to invite my friends to come over for a meal. I'm not so happy when I'm having a meal without my friends. I ask them to join me to share a meal so that we can be chatting as we eat ... I do not share food with others because I expect them to act in the same way. If I go to a person's house and food is offered to me, I will eat; if food is not offered, that's fine.

The key point here is that food-sharing is not always about survival, it is also about living as a community. This explains why Akenji said that he does not share food because he expects to get food from others when in need. Foodsharing displays a spirit of togetherness, which is an integral part of the SSE.

Crucially, in rural communities in particular, food-sharing enables people to meet personal goals, in this case, sociability. Akenji, as mentioned earlier, invited his friends to share his food with them so that they could chat over the meal. By having a discussion over food, Akenji satisfies his need for sociability. The point I'm emphasising here is that even low-income individuals do not always pursue economic goals, and at times they place more emphasis on pursuing non-economic goals, which is quite different from the capitalocentric notions of economy. Spending time with others enabled Akenji to meet a social need. In other words, meeting social goals is equally as important as meeting economic ones.

In urban areas, food-sharing is part of the low-income population's interdependent lifestyle and ensures that they have access to food. As explained by Lucy, a slum resident in Yaoundé:

In the beginning of the month, when I have money, I stock up food, so everything goes on well. By midmonth, like most people in my community, I don't have money; I just have to survive. During this period, when a person is cooking, about five neighbours would tell the person that their plates are ready. Sometimes we [i.e. people in the neighbourhood] come together to cook food. A person may bring rice, another person brings this, another [person] brings that and we cook and eat. There is solidarity in our neighbourhood. At times a person might decide to cook food in a big pot and we all sit together and eat. That's how we survive. At times I cook and call my neighbours to come and eat. Sometimes I do not even have to call them; I will 
hear a knock on the door and a neighbour would say that she is smelling the food's aroma. I do that too; I go to a neighbour and I say that I'm hungry. We survive by sharing. At times I don't have food and don't tell anyone, but I will hear a knock on the door and when I open the door, I will be given a good plate of food; it is God providing.

Lucy is emphasising the notion of interdependence, which is foundational to the SSE. Poor urbanites depend on one another in order to obtain food, as without such practices, many of them would go hungry. This is precisely why she kept stressing the importance of the practice for their survival.

In Cameroon, food-sharing cuts across boundaries of kin. Sahlins (1972) suggested that people are more inclined to share with close kin than with other members of the community, but in the slums in Yaoundé, Douala, and Bamenda, people share food with members of their community who are not kin. The people with whom Lucy shared food were not her kin, and in fact, her community was made up of people from various ethnic backgrounds. The fact that food-sharing happens among people from different ethnic backgrounds suggests that kin identity is not the principal determinant of its occurrence.

Clearly, food-sharing in urban Cameroon is based on the notion of reciprocity. People share food with others when they have the expectation that it will be reciprocated (Gould, 1981; Cashdan, 1982). As described by Amelia:

There was a neighbour who did not like to share, but she came to my place on a regular basis in the morning around the time she knows that I have breakfast. She will say that I just came to greet you, find out how you are doing, or find out how you slept. When she visits me during breakfast I share the food. It came to a point where I already knew that she will be coming to visit me, so I would keep her share of the food. At times she will request food, sometimes she won't request food, but I already knew that she didn't come to visit me. When she was about to go somewhere, she will stop by my place and use my perfume. One day I went to her place and I used her perfume; she wasn't happy that I used it. That's the same person who usually stopped by my place to use my things, but she told me not to use her things. So, I also told her not to use my things. From that day, we stopped sharing things. It was hard to have a meal in her house.

Amelia suggests that food-sharing, like other forms of exchange, has reciprocal obligations, and that no individual is a perpetual giver or receiver. In other words, at one point the receiver of food is expected to become the giver. As stability is not the norm in the lives of the low-income population, it is by upholding these unwritten rules that they are able to have food on their needy days. The stability of the relationship between low-income individuals is based on respect for these rules. This explains why Amelia indicated that sharing with her neighbour eventually came to an end - because that party was constantly on the receiving end and did not want to give back. As Stack (1974) noted in All Our Kin, reciprocal obligations endure as long as both parties are mutually satisfied. Amelia could not draw upon the credit accumulated with the other party, and so the relationship had to come to an end. The behaviour of the neighbour who was not willing to reciprocate could be equated with Sahlins (1972) notion of 'negative reciprocity', as she was seeking to obtain/receive but unwilling to return the favour. Notions of reciprocity are vital to the functioning of food solidarity in these communities.

\section{CONCLUSION}

In this paper, I have examined the inner workings of food solidarity in various communities in Cameroon. For the low-income population, food solidarity enables them to eat in times of need. Food-sharing highlights the importance of social context and social relations. The vital role of social relationships in the provision of people's daily basic needs supports the compelling point made by Polanyi (2001) and Thurnwald (1932), in that a human-oriented economy is a social affair. 


\section{REFERENCES}

African Development Bank [AfDB]. (2012). African Economic Outlook 2012: Promoting Youth Employment. www.undp. org/content/dam/rba/docs/Reports/African\%20Economic\%20Outlook\%202012\%20En.pdf.

Agyeman, J. \& McEntee, J. (2014). Moving the Field of Food Justice Forward Through the Lens of Urban Political Ecology. Geography Compass, 8(3), 211-220.

Allard, J. \& Matthaei, J. (2008). Introduction. In J. Allard, C. Davidson \& J. Matthaei, J. (eds.), Solidarity Economy: Building Alternatives for People and Planet. Change Maker Publications.

Alliance 21. (2001). Proposal Paper on the Solidarity Economy Workgroup on the Solidarity Socioeconomy. Alliance 21. http:// infotek.alliance2 1.org/d/f/1936/1936_ENG.pdf.

Amin, J. (2012). Understanding the Protest of February 2008 in Cameroon. Africa Today, 58(4), 21-43.

Bateman, M. (2015). Rebuilding Solidarity-Driven Economies after Neoliberalism: The Role of Cooperatives and Local Developmental States in Latin America. In P. Utting, P. (ed.), Social and Solidarity Economy: Beyond the Fringe (pp. 150-165). Zed Books/UNRISD.

Berazneva, J. \& Lee, D. (2013). Explaining the African Food Riots of 2007-2008: An Empirical Analysis. Food Policy, $39(\mathrm{C}), 28-39$.

Cashdan, E.A. (1982). Egalitarianism Among Hunters and Gatherers. American Anthropologist, (82), 116-120.

Defourny, J., Develtere, P., Fonteneau, B. \& Nyssens, M. (eds.). (2009). The Worldwide Making of the Social Economy, Innovations and Changes. Acco.

Eme, B. \& Laville, J.-L. (2006). Economie solidaire. In J.-L. Laville \& A.D. Cattani (eds.), Dictionnaire de l'autre économie (pp. 303-312). Gallimard.

Fonteneau, B., Ojong, N., Neamtan, N, Wanyama, F. et al. (2011). Social and Solidarity Economy: Our common road towards Decent Work. ILO.

Gismondi, M., Connelly, S., Beckie, M., Markey, S. \& Reseland, M. (2016). Scaling up: The Convergence of Social Economy and Sustainability. AU Press.

Hillenkamp, I. (2013). L'économie solidaire en Bolivie. Entre marché et démocratie [The solidarity economy in Bolivia. Between market and democracy]. Karthala.

Holt G., E. (2011). Food Security, Food Justice or Food Sovereignty. In A. Alkon \& J. Agyeman (eds.), Cultivating Food Justice. Race, Class and Sustainability. MIT Press, Cambridge.

Holt G., E. \& Shattuck, A. (2011). Food Crises, Food Regimes and Food Movements: Rumblings of Reform or Tides of Transformation? The Journal of Peasant Studies, 38(1), 109-144.

Gibson-Graham, J.K., (2006). A Postcapitalist Politics. University of Minnesota Press.

Gould, R.A. (1981). Comparative Ecology of Food-Sharing in Australia and California. In R.S.O. Harding \& G. Teleki (eds.), Omnivorous Primates. Gathering and Hunting in Human Evolution. Columbia University Press.

Laville, J-L. (2015). Social and Solidarity Economy in Historical Perspective. In P. Utting (ed.), Social and Solidarity Economy: Beyond the Fringe (pp. 41-56). Zed Books/UNRISD.

Laville, J-L. (1992). Les services de proximite en Europe. Vuibert.

Lewis, M. \& Conaty, P. (2012). The Resilience Imperative. New Society.

Loh, P. \& Agyeman, J. (2019). Urban Food Sharing and the Emerging Boston Food Solidarity Economy. Geoforum, 99, 213-222.

Loh, P. \& Shear, B. (2015). Solidarity Economy and Community Development: Emerging Cases in Three Massachusetts Cities. Community Development, 46(3), 244-260.

Mbuli, C.S., Fonjong, L.N. \& Fletcher A.J. (2021). Climate Change and Small Farmers' Vulnerability to Food Insecurity in Cameroon. Sustainability, 13(3), 1523. 
McClintock, N. (2014). Radical, Reformist, and Garden-Variety Neoliberal: Coming to Terms with Urban Agriculture's Contradictions. Local Environ. Int. J. Just. Sustain, 19 (2),147-171.

McLaren, D. \& Agyeman, J. (2015). Sharing Cities. MIT Press.

Mendell, M. \& Neamtan, N. (2010). The Social Economy in Quebec: Towards a New Political Economy. In L. Mook, J. Quarter \& S. Ryan (eds.), Why the Social Economy Matters (pp. 32-58). University of Toronto Press.

McMurtry, J-J. (2009). Living Economies. Canadian Perspective on the Social Economy, Co-Operatives, and Community Economic Development. Edmond Montgomery Publications.

Nembhard, J.G. (2020). 'Building a Cooperative Solidarity Commonwealth'. In J. G. Speth \& K. Courrier (eds.). The New Systems Reader: Alternatives to a Failed Economy (pp. 273-284). Routledge.

Nembhard, J. G. (2014). Collective Courage: A History of African American Cooperative Economic Thought and Practice. Pennsylvania State University Press.

National Institute of Statistics [NIS]. (2015a). National Report on the Millennium Development Goals in 2015. CM: NIS.

NIS. (2015b). Presentation of the First Results of the Fourth Cameroon Household Survey (ECAM) of 2014. CM: NIS.

North, P. \& Cato, M. (2017). Introduction: New Economies North and South-Sharing the Transition to a Just and Sustainable Future. In Towards Just and Sustainable Economies: The social and solidarity economy North and South. Policy Press.

Ojong, N. (2015). Social Finance for Social Economy. Working Paper N. ${ }^{\circ}$ 67. International Labour Organisation, Geneva. Polanyi, K. (2001). The Great Transformation: The Political and Economic Origins of Our Time. Beacon Press.

Quiñones Jr., B.R. (2008). Facets of Solidarity Economy. In M. Arruda (ed.), A Non-Patriarchal Economy is Possible: Looking at the solidarity economy from different cultural facets. Alliance for a Responsible, Plural and Solidarity-based Economy (pp. 17-85). ALOE.

Sahakian, M. \& Dunand, C. (2015). The Social and Solidarity Economy Towards Greater 'Sustainability’: Learning Across Contexts and Cultures, From Geneva to Manila. Community Development Journal, 50(3), 403-417.

Sahlins, M. (1972). Stone Age Economics. Aldine Atherton, Inc.

Servet, J-M. (2007). Le principe de réciprocité chez Karl Polanyi. Contribution à une définition de l'économie solidaire. Revue Tiers Monde, 190(2), 255-273.

Stack, C. (1974). All our Kin: Strategies for Survival in a Black Community. Harper \& Row.

Thurnwald, R. (1932). Economics in Primitive Communities. Oxford University Press.

Utting, P. (2015). Social and Solidarity Economy Beyond the Fringe. Zed Books.

World Food Programme [WFP]. (2018). WFP Cameroon Country Brief. WFP. https://docs.wfp.org/api/ documents/1a79575773dd64db394c2b27f17aa511f/download/?_ga=2.136980912.1407090356.1529351037708273017.1528572362

World Bank. (2021). The World Bank in Cameroon. The World Bank. www.worldbank.org/en/country/cameroon/ overview.

Veltmeyer, H. (2018). The Social Economy in Latin America as Alternative Development. Canadian Journal of Development Studies, 39(1), 38-54. 